\title{
KEMENANGAN JADIN DAN INTERAKSI SOSIAL PADA PEMILUKADA 2017 KABUPETAN NAGAN RAYA
}

\author{
1) Sudarman Alwy 2) Misnawati \\ 1. Fakultas Ilmu Sosial dan Ilmu Politik Universitas Teuku Umar \\ Email. darman76alwy@gmail.com \\ 2. Fakultas Ilmu Sosial dan Ilmu Politik Universitas Teuku Umar
}

\begin{abstract}
ABSTRAK
Keikutsertaan masyarakat dalam Pemilukada sebagai wujud kepedulian sosial terhadap kebijakan pemerintah dalam memilih pemimpin yang dianggap layak dan cakap untuk memimpin. Penelitian ini bertujuan untuk mengetahui bagaimana peran kapital sosial dalam kemenagan Jadin pada Pemilukada 2017 Kabupaten Nagan Raya. Penelitian ini menggunakan metode kualitatif dengan pendekatan deskriptif analisis yang melibatkan informan secara purposive purposive sampling terdiri dari 5 orang infoman. Pengumpulan data dilakukan dengan observasi, wawancara dan dokumentasi dengan pengujian keabsahan data memakai triangulasi. Hasil penelitian menunjukkan bahwa Kapital sosial dominan yang ditampilkan dalam arena perpolitikan adalah dengan membangun interaksi dan saweu gampong. Pasangan Jadin intens melakukan silaturrahim ke semua lapisan masyarakat yang difasilitasi oleh tim yang dinamakan Tim Pejuang Jadin yang memang sudah terbentuk setahun sebelum Pemilukada, lewat kerja massif tim inilah kemudian visi-misi serta program unggulan Jadin tersampaikan secara utuh kepada masyarakat sehingga pada akhirnya masyarakat mayoritas menjatuhkan pilihannya pada Jadin.
\end{abstract}

Kata kunci ; Interaksi Sosial, Tim Pemenangan, dan Pemilukada

\section{PENDAHULUAN}

Pemilihan Umum Kepala Daerah atau yang biasa disingkat dengan Pemilukada atau Pilkada, adalah pemilihan umum untuk memilih Kepala Daerah dan Wakil Kepala Daerah secara langsung di Indonesia oleh penduduk daerah setempat yang memenuhi syarat. (Abas, 2012: 31)

Suatu hal yang menarik juga ketika kita coba membahas dan mencermati proses pelaksanaan Pemilukada di Propinsi Aceh dengan Otonomi Khususnya yang sudah dilegalkan dalam undang-undang keberadaan partai politik lokal untuk ikut serta dalam persaingan perebutan kekuasaan. Keberadaan parlok ini sendiri menjadi suatu kekhususan bagi Propinsi Aceh yang terakomodir keberadaannya lewat Undang-undang Nomor 11 tahun 2006 tentang Pemerintah Aceh atau yang lebih di kenal dengan 
sebutuan UUPA. Legalitas keterlibatan parlok ini juga diikuti dengan keabsahan bagi calon kepala daerah dari jalur independen sesuai dengan yang termaktup dalam UUPA dengan sendirinya memberikan nuansa politik yang berbeda dengan daerah lain yang ada di Indonesia.

Demikian juga halnya dengan keberadaan Kabupaten Nagan Raya sebagai kabupaten 'muda' yang merupakan hasil dari pemekaran Kabupaten Aceh Barat pada tahun 2002 juga ikut dalam pertarungan politik kepala daerah yang sejak dari awal pemekaran di pimpin oleh Drs. H. T. Zulkarnaini (Ampon Bang) selama 5 tahun dan dilanjutkan dengan kemenangan pemilukada 2 kali berturut-turut dengan sendirinya Kabupaten Nagan Raya dibawah kepemimpinan Ampon Bang selama 15 tahun atau 3 (tiga) periode berturut-turut.

Pada Pemilukada tahun 2017 lalu kandidat yang di pelopori oleh Ampon Bang berhasil dipatahkan oleh pasangan baru yang juga merupakan pecahan dari pasangan Ampong Bang periode sebelumnya (2012-2017) Bapak Jamin Idham sebagai Wakil Bupati dulunya juga ikut mendesain kemenangan Ampon Bang-Jamin Idham pada pemilukada sebelumnya. Namun pada pemilukada 2017 lalu Ampon Bang sebagai incomben mendukung TR. Keumangan sebagai jagoan untuk dimenangkan, sementara Jamin Idham (Partai Demokrat) berpasangan dengan Chalidin (Partai Aceh) dengan jargon 'Jadin' juga di dukung oleh beberapa partai lainnya sebagaimana gambar berikut ini:

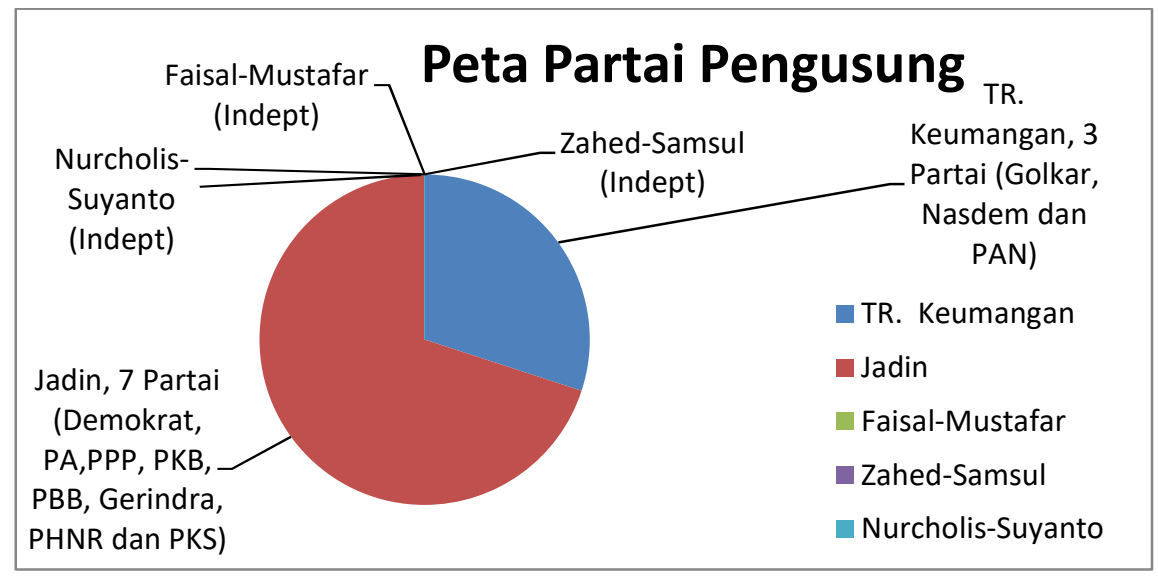

Pasangan JADIN berhasil mengungguli perolehan suara dalam pilkada nagan raya tahun 2017 yang dengan sendirinya sudah mengubah sejarah dan asumsi yang berkembang selama ini bahwa Ampon Bang berhasil membangun dinasti baru, secara otomatis menjadi sejarah baru keberadaan Kabupaten Nagan Raya pasca pemekaran dengan mengalahkan pasangan yang di usung dari partai Golkar yang diketuai oleh Drs. H. T. Zulkarnaini, sebagaimana gambar berikut. 


\section{Perolehan Suara Pilkada Nagan Raya 2017}

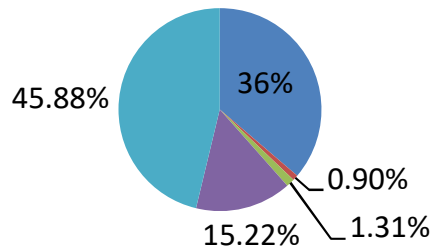

No Urut 1

No Urut 2

No Urut 3

No Urut 4

Keterangan Pasangan dan Nomor Urut: 1. TR.Keumangan, SH, MH. dan Said Junaidi,SE. 2. Faisal A. Qubsy dan Mustafar. 3. drh. Muhammad Zaheb dan Samsul Bahri, Bsc. 4. Nurchalis SP., M. Si dan Suyanto, SE. 5. H.M. Jamin Idham, SE dan Chalidin,SE.

Suatu hal yang menarik untuk di kaji lebih lanjut perihal kemenangan pasangan Jadin khususnya terhadap pasangan yang di dukung penuh oleh incombane dengan kekuatan dan mesin politik yang sudah mapan dalam satu tema penelitian untuk mengetahui Peran Kapital Sosial dalam Kemenangan Jadin pada Pemilukada 2017 Kabupetan Nagan Raya.

\section{TINJAUAN PUSTAKA}

\section{Kapital Sosial (Social Capital)}

Selain human capital dari perspektif pengetahuan dan keterampilan, justru kemampuan masyarakat untuk melakukan asosiasi (berhubungan) satu sama lain juga perlu diperhitungkan dalam pertumbuhan ekonomi masyarakat. Segala kemampuan di atas akan menjadi modal penting bagi pertumbuhan ekonomi serta eksistensi sosial lainnya. Semua bentuk modal ini disebut sebagai 'modal sosial' (social capital), yaitu kemampuan masyarakat untuk bekerja bersama demi mencapai tujuan bersama dalam suatu kelompok dan organisasi (Coleman, 1990: 24)

Fukuyama (1999: 24) dengan tegas menyatakan bawah belum tentu normanorma dan nilai-nilai bersama yang dipedomani sebagai acuan bersikap, bertindak, dan bertingkah-laku itu otomatis akan menjadi modal sosial.

Konsep capital social adalah segala hal yang berkaitan dengan masyarakat yang bertujuan mencapai kualitas hidup yang lebih baik serta ditopang oleh nilai-nilai dan norma sebagai unsur utamanya. Nilai dan norma ini bisa berbentuk kepercayaan, aturanaturan kolektif, dan sebagainya. (Lawang, 2005: 80).

Modal sosial bukan merupakan sebuah entitas (entity) tunggal tetapi berbagai macam entitas yang berbeda, dengan dua elemen bersama: terdiri dari beberapa aspek struktur sosial, dan memfasilitasi tindakan pelaku-pelaku tertentu dalam struktur itu. Sebagaimana bentuk modal lain, modal sosial adalah produktif, membuat mungkin pencapaian tujuan tertentu yang di dalam ketiadaannya akan tidak mungkin. 
Sebagaimana modal fisik dan modal manusia, modal sosial sama sekali tidak fungible tetapi mungkin specific untuk aktivitas tertentu. Tidak seperti bentuk modal lain, modal sosial melekat dalam struktur hubungan antara para pelaku dan diantara para pelaku (Coleman, 1988: 98)

Hasbullah (2006: 75), dimensi inti telaah dari modal sosial terletak pada bagaimana kemampuan masyarakat untuk bekerjasama dalam membangun suatu jaringan guna mencapai tujuan bersama, yaitu tujuan bersama untuk hidup lebih baik dari sebelumnya. Adler dan Kwon (2000: 36) menegaskan bahwa dimensi modal sosial merupakan gambaran dari keterikatan internal yang mewarnai struktur kolektif dan memberikan kohesifitas serta keuntungan-keuntungan bersama dari proses dinamika sosial yang terjadi di dalam masyarakat. Dimensi modal sosial menggambarkan segala sesuatu yang membuat masyarakat bersekutu untuk mencapai tujuan bersama atas dasar kebersamaan, serta diikat oleh nilainilai dan norma-norma yang tumbuh dan dipatuhi oleh anggota masyarakatnya. Dimensi modal sosial inheren dalam struktur relasi sosial serta jaringan sosial dalam suatu masyarakat yang menciptakan berbagai ragam kewajiban sosial, menciptakan iklim saling percaya, membawa saluran informasi, menetapkan norma-norma, dan sangsi-sangsi sosial bagi anggota masyarakat tersebut (Coleman, 2008: 79).

\section{Interaksi Sosial}

Bentuk umum proses sosial adalah interaksi sosial, oleh karena itu interaksi sosial merupakan syarat utama terjadinya aktivitas dalam masyarakat. Bentuk lain dari proses sosial hanya merupakan bentuk-bentuk khusus dari interaksi sosial. Interaksi sosial merupakan hubungan soosiak yang dinamis yang menyangkut hubungan antara orang perorangan, dengan kelompok manusia (Syahrial Syarbaini dan Rudiyanta, 2009: 25-26).

Setiap individu yang berhubungan dengan individu yang lain, baik hubungan sosial antara individu dengan individu, individu dengan kelompok atau kelompok dengan kelompok, hubungan sosial itu memiliki aspek-aspek sebagai berikut(Slamet Santoso, 2004: 11).

1) Adanya hubungan, Setiap interaksi tentu terjadi karena adanya hubungan antara individu dengan individu maupun antara individu dengan kelompok, serta hubungan antara kelompok dengan kelompok. Hubungan antara individu dengan individu ditandai antara lain dengan tegur sapa, berjabat tangan, dan bertengkar.

2) Ada individu, Setiap interaksi sosial menuntut tampilnya individu individu yang melaksanakan hubungan. Hubungan sosial itu terjadi karena adanya peran serta dari individu satu dan individu lain, baik secara person atau kelompok.

3) Ada tujuan, Setiap interaksi sosial memiliki tujuan tertentu seperti mempengaruhi individu lain. 
4) Adanya hubungan dengan struktur dan fungsi kelompok, Interaksi sosial yang ada hubungan dengan struktur dan fungsi kelompok ini terjadi karena individu dalam hidupnya tidak terpisah dari kelompok. Tiap-tiap individu memiliki fungsi dalam kelompoknya. Individu di dalam kehidupannya tidak terlepas dari individu yang lain, oleh karena itu individu dikatakan sebagai makhluk sosial yang memiliki fungsi dalam kelompoknya.

Interaksi sosial juga dilandasi oleh beberapa faktor psikologi, yaitu (Syahrial Syarbaini dan Rudiyanta, 2009: 27) :

1) Imitasi, adalah suatu tindakan meniru orang lain yang dilakukan dalam bermacammacam bentuk, seperti gaya bicara, tingkah laku, adat dan kebiasaan, serta apa saja yang dimiliki atau dilakukan orang lain.

2) Sugesti, muncul ketika si penerima dalam kondisi tidak netral sehingga tidak dapat berpikir rasional. Pada umumnya sugesti berasal dari orang yang mempunyai wibawa, kharismatik, memiliki kedudukan tinggi, dari kelompok mayoritas kepada minoritas.

3) Identifikasi, merupakan kecenderungan sesorang untuk menjadi sama dengan pihak lain, sifatnya lebih mendalam dari imitasi karena membentuk kepribadian seseorang.

4) Simpati, merupakan proses dimana seseorang merasa tertarik dengan pihak lain.

5) Empati, merupakan simpati yang mendalam, dapat mempengaruhi kejiwaan, dan fisik seseorang.

Upaya manusia dalam rangka memenuhi kebutuhan hidupnya dilaksanakan melalui proses sosial yang disebut interaksi sosial, yaitu hubungan timbal balik antara individu dengan individu, individu dengan kelompok, atau kelompok dengan kelompok dalam masyarakat. Terdapat tiga macam interaksi sosial dalam kenyataan sehari-hari (Taufik Rahman, 2000: 21-22).

1) Interaksi antara individu dan individu. Memberi pengaruh, rangsangan, atau stimulus kepada individu yang lainnya. Sedangkan individu yang terkena pengaruh akan memberikan reaksi, tanggapan atau respon. Interaksi antara individu dan individu dapat berwujud dalam bentuk berjabat tangan, saling menegur, bercakap-cakap atau mungkin bertengkar.

2) Interaksi antara individu dan kelompok. Secara konkrit dapat dilihat seorang orator sedang berpidato di depan orang banyak. Bentuk interaksi ini menunjukkan bahwa kepentingan seorang individu berhadapan dengan kepentingan kelompok.

3) Interaksi antara kelompok dan kelompok. Menunjukkan bahwa kepentingan individu dalam kelompok merupakan satu kesatuan, berhubungan dengan kepentingan individu dalam kelompok yang lain. Interaksi ini menunjukkan setiap tindakan individu merupakan bagian dari kepentingan kelompok. 


\section{METODOLOGI PENELITIAN}

Metode yang digunakan dalam penelitian ini adalah metode kualitatif dengan menggunakan pendekatan deskriptif analisis dengan informan yang di pilih secara "purposive sampling"atau sampling bertujuan yang terdiri dari: Ketua tim pemenangan Jadin, Jamin Idham selaku Bupati terpilih, Partai Politik (Parpol) pendukung, tokoh masyarakat dan masyarakat. Pengumpulan data dilakukan dengan observasi, wawancara dan dokumentasi.

\section{HASIL TEMUAN DAN PEMBAHASAN}

\section{Gambaran Umum Lokasi Penelitian}

Kabupaten Nagan Raya merupakan salah satu kabupaten yang ada di wilayah pantai barat selatan provinsi Aceh dengan ibukotanya Suka Makmue. Kabupaten ini terbentuk secara defnitif berdasarkan Undang-Undang Nomor 4 Tahun 2002, tepatnya pada tanggal 2 Juli 2002 sebagai hasil pemekaran dari Kabupaten Aceh Barat. Luas wilayah Kabupaten Nagan Raya sebesar 3.363,72 kilometer persegi $\left(\mathrm{KM}^{2}\right)$ atau sekitar 5.86 persen dari luas wilayah Provinsi Aceh (57.365.5).

Secara geografis kedudukan Kabupaten Nagan Raya berada pada titik kordinat antara $03^{\circ} .40^{\circ}-04^{0} 38$ Lintang Utara (LU) dan 96 $-11-06^{\circ} 48^{\prime}$ Bujur Timur (BT), yang terdiri dari 5 kecamatan, yaitu; Kecamatan Beutong, Darul Makmur, Kuala, Seunagan, dan Kecamatan Seunagan Timur.

Adapun secara geografis berbatasan dengan ;

\section{Temuan dan Pembahasan}

Basis Partai Pengusung

\section{Bupati Jamin Idham (Partai Demokrat)}

Partai Demokrat didirikan oleh Bapak Sosilo Bambang Yudhoyono yang terilhami atas kekalahan terhormat pada pemilihan calon wakil presiden dalam sidang MPR 2001. Hasil pooling publik yang menunjukkan tingginya popularitas yang ada pada diri Sosilo Bambang Yudhoyono, beberapa orang terpanggil nuraninya untuk memikirkan bagaimana sosok Sosilo Bambang Yudhoyono bisa dibawa menjadi Pemimpin Bangsa dan bukan direncanakan untuk menjadi Wakil Presiden Republik Indonesia (RI) tetapi menjadi Presiden RI untuk masa mendatang. Agar cita-cita tersebut terlaksana jalan satu-satunya adalah mendirikan partai politik.

Adapun struktur Dewan Pimpinan Cabang (DPC) Partai Pemokrat Nagan Raya

- Ketua : H. M. Jamin Idham, SE

- Sekretaris Jenderal : Muslem Wawan Saputra, S.Km

- Bendahara : Abdul Razak (sumber kantor DPC Demokrat) 


\section{Wakil Bupati Chalidin (Partai Aceh)}

Partai Aceh lahir sebagai konsekuensi dari penandatangan Naskah Kesepahaman antara Pemerintah Republik Indonesia dan Gerakan Aceh Merdeka yang dilaksanakan di Helsinki pada Senin tanggal 15 Agustus 2005. Sebagai butir turunan dari MoU Helsinki antara RI dan GAM mengenai legalitas pendirian partai lokal di Aceh, maka didirikanlah Partai Aceh yang pada awalnya diusulkan bernama Partai GAM dengan lambang Bulan Bintang namun pemerintah RI menolak usulan tersebut dengan mengeluarkan Peraturan Pemerintah Nomor 77 Tahun 2007 tentang lambang partai. Kemudian Partai GAM di usulkan untuk dibuat kepanjangan menjadi Partai Gerakan Aceh Mandiri (P-GAM) namun hal ini juga terjadi penolakan lagi dengan penamaan partai GAM dan di minta untuk dirubah kembali nama hingga akhirnya menjadi Partai Aceh (PA) berdasarkan kesepakatan yang terbangun antara Wakil Presiden RI Bapak Jusuf Kalla dan Malik Mahmud pada tanggal 8 April 2008.

Dewan Pimpinan Aceh Partai Aceh (DPA-PA) adalah sebagai berikut:

- Ketua : Muzakir Manaf;

- Sekretaris Jenderal : Mukhlis Basyah;

- Bendahara : Hasanuddin Sabon.

Dewan Pimpinan Aceh Partai Aceh (DPA-PA) Kabupaten Nagan Raya sebagai berikut:

- Ketua : : T. Raja Mulia

- Sekretaris : Ferry Achmat Kusairy

\section{Jadin dan Interaksi Sosial}

Interaksi sosial sebagai suatu hubungan timbal balik antara individu dengan individu lainnya, individu dengan kelompok dan sebaliknya. Interaksi sosial memungkinkan masyarakat berproses sedemikian rupa sehingga membangun suatu pola hubungan. Interaksi sosial dapat pula diandaikan dengan apa yang disebut Weber sebagai tindakan sosial individu yang secara subjektif diarahkan terhadap orang lain (Johnson, 1988: 214).

Menurut Kimball Young dalam Taneko (1990: 112), interaksi sosial dapat berlangsung antara:

1. orang-perorangan dengan kelompok atau kelompok dengan orang-perorangan (there may be person to group or group to person relation)

2. kelompok dengan kelompok (there is group to group interaction)

3. orang-perorangan (there is person to person interaction).

Weber mengklasifikasikan ada empat jenis tindakan sosial yang mempengaruhi sistem dan struktur sosial masyarakat yaitu:

1. Rasionalitas instrumental (instrumental rasionality). Sebagai sosok yang pernah memenangkan pemilukada sebelumnya sebagai wakil bupati 2012-2017, Jamin tidak memiliki kendala dalam hal pendekatan sosial kepada masyarakat 
mengingat kedekatan Jamin sebelumnya sebagai wakil bupati dengan masyarakat sudah terbangun ditambah lagi dengan tersedianya fasilitas-fasilitas pendukung yang dimiliki sebagai wakil bupati. Tindakan sekecil apapun yang dilakukan oleh Jamin selaku wakil bupati sudah pasti mendapat perhatian dari masyarakat termasuk kegiatan 'blusukan' ketengah masyarakat secara langsung.

2. Rasionalitas yang berorientasi nilai (value rasionality). Jamin melakukan pendekatan simpatik dengan menghadiri setiap acara yang dilaksanakan oleh masyarakat dengan menyentuh berbagai kalangan masyarakat dan lebih mengetengahkan terhadap komunitas ekonomi menengah ke bawah yang merupakan pemilih manyoritas jika dibandingkan dengan pemilih ekonomi menengah ke atas.

3. Tindakan tradisional (traditional action). Jamin melakukan tradisi turun menurun yang ada dalam kalangan masyarakat Aceh secara umum yaitu menjalin silaturrahim ke masyarakat secara langsung yang biasanya dilakukan tanpa pengawalan dan protokoler selaku pejabat negara wakil bupati. Budaya "sawe gampong" yang rutin dilakukan secara individual oleh Jamin membuat masyarakat tumbuh kepercayaan terhadap Jamin karena dalam anggapan masyarakat menjalin ukhuwah islamiah merupakan tatanan dan anjuran yang sesuai dengan hakikat masyarakat Aceh yang syar'i.

4. Tindakan afektif (affective action). Kunjungan Jamin ke gampong-gampong selaku wakil bupati tanpa adanya pengawalan dari pemerintah menjadikan Jamin sebagai sosok yang sangat merakyat sehingga terkesan tidak ada jarak antara wakil bupati dan masyarakat dalam hal interaksi yang terbangun. Masyarakat merasa kehadirin Jamin bukan semata sebagai kunjungan pejabat yang harus diperhatikan dan dipersiapkan segala sesuatu secara khusus, namun lebih kepada kehadiran sosok saudara yang mengerti akan kondisi dan situasi masyarakat sehingga menjadikan Jamin sebagai sosok pengayom dan pendengar keluh kesah masyarakat yang ada di Kabupaten Nagan Raya untuk dapat diselesaikan baik sewaktu menjabat wakil bupati maupun setelah terpilih menjadi bupati.

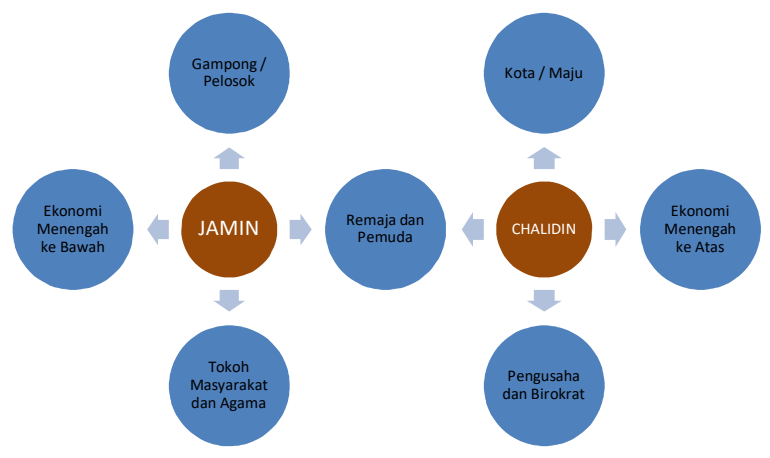

Skema: Pembagian Peran Interaksi Sosial Calon Bupati dan Wakil Bupati 
Pembagian peran dan fungsi yang jelas antara Jamin sebagai calon bupati dan Khalidin sebagai calon wakil bupati menjadikan kemenangan pasangan Jadin ini semakin komplit. Jamin lebih berperan kepada masyarakat ekonomi menengah ke bawah sementara Khalidin lebih kepada pendekatan ekonomi menengah ke atas khsusnya pengusaha sesuai dengan back ground juga pengusaha yang sukses berkiprah di tingkat nasional. Khalidin disamping melakukan pendekatan terhadap pengusaha juga mendekati pemuda sesuai dengan karakter dan penampilan fisik yang masih muda dan energik, sehingga kaum muda pun bisa dengan mudah menerimanya walaupun tidak semua.

Tampilan dari dua tokoh ini yang memperlihatkan back ground bertolak belakang membuat tim pemenangan Jadin pun semakin mudah dalam memasarkan kandidat pasangan Jadin ini dan dapat dilakukan pemetaan terhadap pasar yang akan dimasuki. Bila pasar yang akan didatangi adalah manyoritas masyarakat ekonomi menengah ke bawah, maka Jamin lah yang akan disodorkan untuk dipromosikan sehingga masyarakat dapat dengan mudah menerima. Sebaliknya jika yang akan didatangi adalah tokoh pengusaha atau pemuda, maka Khalidinlah yang dijadikan sebagai produk yang akan dipasarkan.

Keragaman pemilih sangat jamak terjadi ketika pemilihan, tahapan pemilih secara fisik memiliki tingkatan yang berbeda, selaku tim mereka melihat harus ada perbedaan strategi dalam mempengaruhi massa tersebut, dilapangan pemilih memiliki 3 kategori yaitu: pemilih pemula, pemilih dewasa dan pemilih orang tua. Sedangkan secara psikologi ada dua kategori pemilih yaitu: pemilih yang awam dan pemilih yang mempunyai intelektual. Dengan melihat hal ini akan lebih mudah dalam memanajemen golongan masyarakat, seperti pemilih orang tua mereka cenderung di bidang dakwah dan bidang agama.

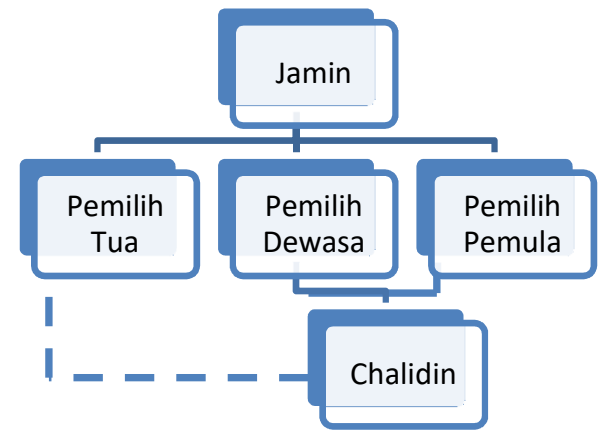

Skema Pendekatan Interaksi Sosial menurut kelompok Pemilih

\section{Jadin dan Kapital Sosial}

Pasangan Jadin memiliki visi yaitu "Mewujudkan Kabupaten Nagan Raya yang sejahtera, mandiri, maju dan berdaya saing melalui pemberdayaan ekonomi masyarakat 
dan peningkatan kualitas sumber daya manusia yang berlandaskan syi'ar Islam”. Untuk mewujudkan visi tersebut, maka dirumuskan beberapa misi sebagai berikut;

1. Mengimplementasikan nilai-nilai keislaman dalam tatanan kehidupan masyarakat serta mewujudkan pelaksanaan syariat Islam secara kaffa.

2. Melakukan reformasi birukrasi menuju pemerintahan yang baik (good governance), bersih dan berwibawa (clean government).

3. Meningkatkan pertisipasi masyarakat dalam proses pengambilan kebijakan.

4. Meningkatkan pemberdayaan ekonomi masyarakat yang berbasis kearifan local menuju masyarakat yang produktif sebagai upaya pemberantasa kemiskinan.

5. Meningkatkan kualitas Sumber Daya Manusia (SDM) dengan memberikan dukungan maksimal terhadap pendidikan formal dan informal.

6. Melakukan perombakan kabinet kerja sesuai dengan disiplin ilmu aparat pemerintahan untuk menstanilkan iklim kerja sesuai dengan perundangundangan.

7. Silaturrahmi dengan masyarakat di Kecamatan-kecamatan, menjaring informasi keunikan dan karakteristik wilayah guna melakukan pembangunan sesuai dengan keadaan daerah setempat.

8. Koordinasi dengan BAPEDA, Dinas Sosial, Keuangan Daerah, Dinas Kesehatan, Dinas Pendidikan, RSUD dan dinas-dinas terkait lainnya dalam periode periode 2017-2022.

Visi dan misi tersebut selanjutnya diterjemahkan dengan 15 program unggulan lainnya yaitu; keagamaan, pendidikan, kesehatan, pertanian, seni dan budaya, ketenagakerjaan, okonomi kerakyatan, santunan kematian sebesar 21 juta rupiah diberikan pada hari ke 5 setelah kematian, santunan melahirkan (gizi bayi), pencegahan banjir di kecamatan rawan terkena dampak banjir, bedah/rahab rumah tidak layak huni bagi masyarakat miskin, beras miskin gratis (raskin gratis), listrik gratis bagi masyarakat miskin, alokasi 20\% ADG untuk kaum perempuan akan di perbubkan (peraturan Bupati), serta kepemudaan dan olahraga. Dengan penjelasan sebagai berikut;

\section{Keagamaan}

Melalui Pemberdayaan dayah / pesantren dan lembaga keagamaan islam lainnya, $\sim$ Memaksimalkan bantuan untuk kesejahteraan pesantren dan dayah, $\sim$ Bantuan/gaji guru seumebeut, $\sim$ Rekomendasi pembangunan pesantren sebagai penopang kesejahtraan aqidah dan ketauhidan di kabupeten Nagan Raya, $\sim$ Meningkatkan peran dinas syariat islam serta mendorong perencanaan program yang mampu mengantisipasi dan memberikan penyadaran terhadap pelaku kemungkaran serta menjalankan syariat islam secara kaffah.

\section{Pendidikan}

Melalui pemberian Beasiswa/subsidi uang kuliah bagi mahasiswa Nagan Raya di dalam dan luar daerah, Pemerataan guru ke sekolah-sekolah pelosok dan seluruh 
kecamatan sehingga guru tidak menempuh disatu sekolah saja, $\sim$ Penambahan tenaga kontrak guru untuk memenuhi kebutuhan guru secara merata, $\sim$ Memaksimalkan fungsi pengawas dan majelis pendidikan daerah sebagai upaya peningkatan pengawasan terhadap manajerial pendidikan dan proses belajar mengajar (PBM), Memberikan fasilitas kepada pemuda-pemudi Nagan Raya.

\section{Kesehatan}

Melalui memaksimalkan pelayanan di RSUD Kabupaten Nagan Raya secara menyeluruh, $\sim$ Penambahan dokter spesialis, $\sim$ Meratakan tenaga medis keseluruhan puskesmas yang ada dalam kabupaten Nagan Raya.

\section{Pertanian}

Menerapkan sistem tanam serentak, $\sim$ Subsidi ongkos bajak sawah (olah tanah) yang dilakukan dengan teknis bantuan hand trak-tor, $\sim$ Pupuk gratis bibit gratis, $\sim$ Pembangunan akses /infrastruktur pertanian seperti jalan untuk akses pertanian.

\section{Seni dan budaya}

Malaksanakan pekan seni dan budaya/pameran seni dan budaya/festival seni dan budaya Kabupaten Nagan Raya sebagai upaya mendukung promosi dan membumikan kesenian dan kebudayaan lokal Nagan Raya yang nyaris punah. Pekan/pameran seni dan budaya lebih memfokuskan promosi seni dan budaya lokal baik berbentuk benda, makanan khas dan seni/budaya tak benda.

\section{Ketenaga kerjaan}

Menciptakan akses lapangan kerja dikabupaten Nagan Raya, Meng-advokasi akses lapangan kerja yang mengutamakan putra putrid Nagan Raya baik di pemerintah dan perusahaan swasta lainnya, Membangun badan usaha milik daerah (BUMD) sebagai upaya penopang pendapatan asli daerah (PAD) dan menekan angka pengangguran.

\section{Ekonomi}

Memberikan modal usaha kepada pelaku usaha kecil menengah yang disesuaikan dengan kondisi dan kebutuhan usaha masyarakat.

\section{Santunan kematian sebesar 21 juta rupiah diberikan pada hari ke 5 setelah kematian}

Pemerintah akan meng-asuransikan seluruh masyarakat Nagan Raya supaya terjamin kesejahteraan sosialnya. Sesuai dengan UU Nomor 40 tahun 2004 tentang system jaminan sosial pasal 18 huruf (E) dimana jenis program jaminan sosial adalah jaminan/asuransi kematian. Manfaat jaminan kematian berupa uang tunai dibayarkan paling lambat 3 (tiga hari) kerja setelah klaim diterima dan disetujui oleh badan penyelenggaraan jaminan sosial (BPJS). 


\section{Santunan melahirkan (gizi bayi)}

Sebagai upaya pencapaian salahsatu program MDGs (millennium developments goals) yang merupakan kesepakatan 189 kepala Negara yang masuk dala perserikatan bangsa-bangsa (PBB) untuk menurunkan angka kematian anak, pemenuhan gizi bayi dan meningkatkan kesehatan ibu.

\section{Pencegahan Banjir.}

Melakukan kajian penyebab terjadinya banjir dengan mengundang pakar-pakar untuk meneliti lebih lanjut penyebab terjadinya banjir tahunan supaya pada saat pengambilan kebijakan tepat sasaran. Kebijakan tersebut juga tidak terlepas dari konsep kebijakan penggulangan banjir Indonesia, Jika rekomendasi dari kajian pakar sudah ada, kita langsung lakukan upaya pencegahan, $\sim$ Melakukan prakiraan banjir oleh dinas terkait, dan secepat mungkin diberitahukan warga . supaya warga siap siaga, Jika banjir terjadi, pemerintahan Jadin jika terpilih insyaallah akan melakukan upaya konkret misalnya bantuan segera kebutuhan hidup sehari-hari dan perbaikan sarana dan prasarana, pembersihan dan rekonstruksi pasca banjir, rehabilitas dan pemulihan kondisi fisik dan non-fisik, penilaian kerusakan/kerugian dan asurans bencana.

\section{Bedah/rehab Rumah Tidak Layak Huni.}

Program ini akan melibatkan perusahaan swasta yang beroperasi di Kabupatn Nagan Raya untuk memaksimalkan anggaran CSR yang terencana dan terarah untuk masyarakat Nagan Raya.

\section{Beras Miskin Gratis (Raskin Gratis)}

Raskin gratis akan diberikan kepada masyarakat miskan sebagai upaya subsisi kebutuhan pangan bagi masyarakat Nagan Raya.

\section{Listrik Gratis}

Masyarakat miskin penggunaan listrik dengan biaya bulanan kurang dari 50.000 akan dibayar oleh pemerintahan daerah dengan ketentuan yang akan diatur dalam teknis bantuan listrik gratis.

\section{Alokasi 20\% ADG Khusus Perempuan.}

Penggunaan alokasi dana gampong (ADG) akan di atur dalam PERBUB. Khusus untuk kegiatan perempuan akan dialokasikan sebesar $20 \%$ dari seluruh alokasi dana gampong (ADG).

\section{Kepemudaan dan Olah Raga}

Memaksimalkan komite nasional pemuda Indonesia Kabupate Nagan Raya(KNPI) sebagai induk organisasi kepemudaan di Kabupaten Nagan Raya, $\sim$ Memaksimalkan fungsi komite olahraga nasionalmindonesia (KONI) Kabupaten 
Nagan Raya sebagai induk pengurus cabang (PENGCAB) olahraga yang ada dalam Kabupaten Nagan Raya melalui support anggaran

Visi dan misi yang sudah di susun tersebut tentu saja menjadi baro meter yang bagi masyarakat untuk dapat mempertimbangkan sebelum menentukan pilihan. Sebagai bentuk modal (kapital) sosial yang dimainkan oleh pasangan Jamin Idham dan Chalidin dalam memenangkan pemilukada ini melalui beberapa strategi pendekatan dalam mengait simpatik pemilih sesuai dengan porsi kelompok pemilih itu sendiri yang meliputi pemilih pemula, pemilih dewasa dan pemilih orang tua yang sudah mulai dimainkan dalam masa pemenangan dan sekaligus menjadi ukuran keseriusan yang dapat di nilai oleh masyarakat.

Pendekatan untuk pemilih pemula dilakukan secara komprehensif oleh Jamin selaku wakil bupati dan juga tim pemenangan dengan menjual jargon perubahan terhadap masyarakat. Selaku wakil bupati Jamin dapat dengan mudah mengakses lokasi-lokasi sebaran pemilih pemula dengan mengetengahkan visi dan misi yang sudah tersusun dengan baik. Pendekatan lainnya juga dilakukan oleh khalidin sebagai calon wakil bupati yang masih muda untuk dapat memotivasi pemilih pemula dalam menentukan pilihan pada pemilukada yang akan datang. Sosok muda dan energik Chalidin dapat dengan mudah diterima oleh kalangan pemilih pemula yang notabenenya adalah Anak Baru Gede (ABG).

Sementara kalangan pemilih dewasa Jamin melakukan pendekatan dengan komunikasi persuasif mengenai Nagan Raya yang lebih baik dengan mengusung jargon perubahan dan memberikan gambaran perbandingan masa kepemimpinan sebelumnya ketika Jamin sebagai wakil bupati dengan menggambarkan beberapa arah kebijakan untuk perbaikan dari mekanisme yang sudah ada sehingga pemahaman masyarakat dalam memahami rencana perubahan yang di usung oleh pasangan Jadin bukanlah sesuatu yang mustahil untuk dilakukan dan terlihat memang harus dilakukan sehingga isu perubahan tersebut menjadi logis dan dapat diterima oleh masyarakat. Demikian juga halnya pendekatan yang dilakukan oleh Chalidin terhadap kelompok ini dengan menggambarkan bahwa usaha masyarakat dapat dikembangkan lebih besar seperti yang ada sekarang ini berdasarkan pengalamannya yang sudah berkiprah di tingkat nasional sebelumnya. Gambaran keberhasilan dalam usaha ini dapat diterima dengan baik oleh masyarakat berdasarkan profile calon wakil bupati sendiri merupakan putra Nagan Raya yang berkiprah di tingkat nasional sebagai pengusaha.

Perpaduan dua pendekatan terhadap kelompok pemilih dewasa terlihat efektif dalam menjual pasangan Jadin ketengah masyarakat. Program dan jargon perubahan yang di usung oleh pasangan Jadin dapat dengan mudah di kemas oleh tim pemenangan di berbagai wilayah lingkup Kabupaten Nagan Raya dan masyarakat dapat menerima berbagai argumentasi tersebut dalam menentukan pilihan.

Lain halnya pendekatan yang dilakukan oleh pasangan Jadin terhadap pemilih orang tua. Pemilih orang tua ini tidak dapat disamaratakan dengan pemilih pemula dan 
pemilih orang dewasa. Pemilih orang tua ini didekati oleh pasangan jadin ini dengan mengedepankan rencana strategis terhadap pengembangan agama menuju Kabupaten yang Syar'i dan sesuai dengan tatanan nilai-nilai keislaman. Keberadaan komunitas masyarakat pemilih tua ini di Nagan Raya yang di nilai fanatik, maka isu perubahan dalam hal pengembangan program yang berkaitan dengan penguatan keagamaan dapat diterima oleh masyarakat tua termasuk isu pemberian santunan kematian.

\section{PENUTUP}

Berdasarkan hasil penelitian dan pembahasan, hasil penelitian tentang Kemenangan Jadin dan Kapital Sosial pada Pemilukada 2017 Kabupetan Nagan Raya kapital sosial dominan yang ditampilkan dalam arena perpolitikan adalah dengan membangun interaksi sosial dan saweu gampong. Pasangan Jadin intens melakukan silaturrahim ke semua lapisan masyarakat yang difasilitasi oleh tim yang dinamakan Tim Pejuang Jadin yang memang sudah terbentuk setahun sebelum Pemilukada, lewat kerja massif tim inilah kemudian visi-misi serta program unggulan Jadin tersampaikan secara utuh kepada masyarakat sehingga pada akhirnya masyarakat mayoritas menjatuhkan pilihannya pada Jadin.

\section{DAFTAR PUSTAKA}

A.B. Susanto. 2009. Reputation Driven Corporate Social Responsibility pendekatan Strategi Management dalam CSR. Jakarta: Esensi Erlangga Group.

Adman, Nursal 2004. Political Marketing: Strategi Memenangkan Pemilu. Gramedia Pustaka Utama

Ardial. 2010. Komunikasi Politik. Jakarta: indeks.

Arifin, Anwar. 2006. Ilmu Komunikasi: Sebuah Pengantar Ringkas. Jakarta. PT. Raja Grafindo Persada.

Arikunto, Suharsimi. 2009. Prosedur Penelitin Suatu Pendekatan Praktik. Jakarta: Rineka Cipta.

Cangara, Hafied. 2014. Pengantar Ilmu Komunikasi. Jakarta. PT. Raja Grafindo Persada.

2009. Komunikasi Politik: Teori, Konsep dan Strategi. Jakarta: PT Raja Grafindo Persada.

Dan Nimmo. 2005. Komunikasi Politik. Komunikator, Pesan, dan Media. Edisi Terjemahan oleh Tjun Surjaman. Bandung: Remaja Rosdakarya.

Firmanzah. 2008. Marketing Politik Antara Pemahaman dan Realitas, Edisi kedua, Yayasan Obor Indonesia, Jakarta. 
Lilliker, Darren G. 2006. Key Concepts in Political Communication Sage Publication: london.

McNair, Brian. 2011. An Introduction to Political Communication. Fifth Edition. Oxon: Routledge.

Miles B, Matthew dan Huberman. 2007. Analisis Data Kualitatif. Jakarta: Universitas Indonesia Press.

Moleong, Lexi J. 2002. Metode Penelitian Kualitatif. Bandung: PT. Remaja Rosda Karya.

Muhtadi, Suep Saeful. 2008. Komunihasi Politik Indonesia: Dinamika Islam Politik Pasca Orde Baru, Bandung: Remaja Rosda Karya.

Nasution, LK. 2007. Stres pada Remaja. Universitas Sumatra Utara.

Prihatmoko, Joko J. 2003. Pemilu 2004 dan Konsolidasi Demokrasi. Semarang: LP21 Press.

Rahman, Reza. 2009. Corporate Social Responsibility: Antara Teori dan Kenyataan. Yogyakarta: Media Pressindo.

Rizkiyansyah. 2007. Pemilu dan Demokrasi. Jakarta: Ghalia Indonesia.

Rush, Michael dan Althoff, Philip. 2008. Pengantar Sosiologi Politik, an Introduction to Political Sociologi. Jakarta: Rajawali Pers.

Ruslan, Rosady.2005. Manajemen Public Relation dan Media Komunikasi (Konsep dan Aplikasi). PT. Raja Grafindo Persada. Jakarta

Sugiyono. 2011. Metode Penelitian Pendidikan (Pendekatan Kalitatif, kulitatif dan R\&D). Bandung: Alfabeta.

Surbakti, Ramlan. 2010. Memahami Ilmu Politik. Jakarta: PT. Grasindo. 